\title{
A NON-PARAMETRIC ASSESSMENT OF EFFICIENCY OF SOUTH AFRICAN PUBLIC UNIVERSITIES ${ }^{1}$
}

\section{T. V. Nkohla*}

e-mail: vuyolwethu.nkohla@gmail.com / https://orcid.org/0000-0003-2426-9509

\section{Simatele*}

e-mail: msimatele@ufh.ac.za / https://orcid.org/0000-0001-9182-2701

\section{N. Marwa}

Economics and Management Sciences

University of Stellenbosch Business School

Bellville, South Africa

email: nyankomo@sun.ac.za

\section{R. Ncwadi}

Business and Economic Sciences

Nelson Mandela University

Port Elizabeth, South Africa

email: ronney.ncwadi@mandela.ac.za

*Management and Economics

University of Fort Hare East London Campus

East London, South Africa

\section{ABSTRACT}

This article seeks to assess the efficiency of 23 South African public universities using a Data Envelope Analysis (DEA) model for the period 2009-2016. A recent study on this subject matter found a decline in the average TE score of the South African public universities from 83 per cent in 2009 to 78 per cent in 2013. However, the study did not account for non-academic staff among other input variables that are assumed to potentially influence performance outcomes of the universities. We believed that a biased conclusion on the subject matter is likely if academic staff are assumed to dominate efficiency of public universities in South Africa, while the effort of nonacademic staff is not considered. In this respect, our model incorporates both academic and nonacademic staff as input variables among others. Our findings show that over the study period 2009-2016 the average Technical Efficiency (TE) of the South African public universities increased from 91 per cent to 95 per cent. For this result in particular, we deduce that in assessing efficiency of South African public universities, academic and non-academic staff can be deemed as mutually inclusive variables and therefore, neglecting either of the two can lead to biased estimated average TE scores. In addition to this empirical contribution, we also estimate scale and pure efficiency. Our findings show that on average South African public universities are relatively 
better off in scale efficiency (at $97 \%$ ) as compared to pure technical efficiency (at $96 \%$ ). The efficiency levels provided in this study can be used as performance benchmarks for identifying potential improvements required to reach a satisfactory level of efficiency.

Keywords: Data Envelope Analysis, efficiency; higher education; public universities; South Africa.

\section{INTRODUCTION}

The Higher Education (HE) system in South Africa has been going through an exercise of transformation in order to redress the educational imbalances of the past. The funding of $\mathrm{HE}$ institutions (HEIs) was one of the changes used to transform the HE system in South Africa. Funding of HE in South Africa remained the key challenge as the HEIs were characterised by insufficient funding due to a steady decline of funds (Wangenge-Ouma and Cloete 2008; Akor and Roux 2006). The transformation agenda of HE led to the expansion of HE which put serious constraints on state funding of HEIs and those from poor backgrounds accessing HE (Allais 2017). The post-apartheid government established a mechanism of increasing access to HE by providing the National Student Financial Aid Scheme (NSFAS) to poor deserving students (Wangenge-Ouma 2012). This massification triggered a funding crisis, highlighting the need for improved methods of assessing and analysing efficiencies, as well as a clearer understanding of HE funding.

The fundamental financial problems faced by HEIs are a worldwide phenomenon, linked to the increasing cost of education per student and the pressure to increase enrolments (Johnstone 2006). Challenges of declining funds in universities (most South African public universities are funded mainly by government) has sparked protests by students in South Africa demanding that fees must fall. In 2015/2016, the country experienced rising protests of students demanding free education. Protesting students across the country have shown that the current system of funding South Africa's university education is wrong.

$\mathrm{HE}$ is important in driving development in the economy, and measuring the efficiency is important due to government's significant contribution to funding. Evaluating efficiency of HE will be important because if the sector operates efficiently, it will free some funds to help fund many students who enter the system. The measure of efficiency in public institutions is a growing concern due to the expansion of the HE system, therefore it is important for HEIs to cater for the significant growth of the diverse population of students in an efficient manner (Cunha and Rocha 2012).

Efficiency is a means for enhancing fiscal return, that is, reducing waste and generating the best possible fiscal outcomes, and these are the main determinants of efficiency in the public sector. The discourse of measuring efficiency is dominated by two models: Stochastic Frontier 
Analysis (SFA) and Data Envelope Analysis (DEA) (Gromov 2017). However, there is still no general consensus on which of the two models best measures efficiency of HEIs as studies adopt the model that best suit their objectives, data and sample (Barra, Lagravinese, and Zotti 2015).

Stochastic Frontier Analysis (SFA) is a parametric approach that was pioneered by Aigner, Lovell, and Schmidt (1977) and Meeusen and Van den Broeck (1977). In terms of the SFA model the crucial idea is that the error term has two parts: a random error term and an inefficiency term. The advantage of the SFA model is that when estimating the technical efficiency (TE), it acknowledges that there are random shocks which are beyond the control of the producer that can affect output. The ability to check the stochastic error component of the econometric estimation is another benefit of the SFA according to Marwa and Aziakpono (2016). The SFA model's primary limitation includes the possibility that its production function may be mis-specified and the unresolved problems in the real probability distribution of the random component can lead to biased estimations (Marwa and Aziakpono 2016).

Data Envelope Analysis (DEA) is a non-parametric model developed by Charnes, Cooper and Rhodes (1978). This model has been widely utilised in the performance evaluation of financial institutions, universities, hospitals and health organisations, manufacturing and service industries (Emrouznejad, Parker, and Tavares 2008). In the South African context, a recent study by Myeki and Temoso (2019) uses DEA to examine efficiency of public universities. Apart from the fact that the model has been widely utilised in the public sector where outputs are not sold on the market (Mattsson et al. 2018), Myeki and Temoso (2019) justify their primary preference for DEA based on multiple performance indicators inherent with public universities in South Africa. In the view of Johnes and Tone (2017), DEA is very useful in cases where there is a multiplicity of inputs used to produce a multiplicity of outputs, and where market prices are not available.

The DEA model is also very useful when the sample size is small. Furthermore, unlike parametric models DEA does not need an assumption of a functional form linking inputs to outputs and the distributional assumption of the error term (Johnes and Tone 2017). One of the main limitations of the DEA technique is its deterministic nature, and therefore this technique is referred to as a non-statistical method (Mattsson et al. 2018). Resampling techniques such as the bootstrap procedure suggested by Simar and Wilson (1998) can help with this issue to some degree. Following the contrast made between the two models, DEA can be assumed to be the most appropriate technique of evaluating efficiency of HEIs in South Africa.

Financial constraints have called for more diversification of funding sources, accountability and cost effectiveness by HEIs (Ahmad, Farley, and Naidoo 2012). Evaluation 
of efficiency in public universities would be an important step in demonstrating how this technique would help HEIs to identify the need to improve their performance and would allow government and all interested stakeholders to evaluate the efficiency of HEIs. Moreover, as a significant sum is received by the HE sector from government funds, it is vital to monitor this sector on a regular basis for its performance and productivity (Johnes 2008). Therefore, using available funds efficiently is a serious concern for HE.

In the current environment, where public budgets for HE are declining and tuition fees are increasing, there is a sense of urgency to better track the performance of universities in the hope that costs can be contained without compromising quality and accessibility. For universities, improving productivity will be evident in an increasing number of graduates, and an increasing amount of learning, research and innovation relative to the inputs used such as enrolment of students, academic and non-academic staff, and university expenditure. Therefore, this could be used as the most promising strategy that could be adopted in an effort to keep high quality university education as affordable as possible.

Given the above background, at this point it is important to note that the contribution made by Myeki and Temoso (2019) speaks directly to our concern, however, their empirical investigation neglects non-academic staff as input variable that can possibly and significantly drive efficiency of public universities in South Africa. After all, non-academic staff are involved in soliciting for funding with relevant stakeholders while some provide a great deal of support in administration and general work. Baltaru (2019) asserts that non-academic staff ensure a smooth roll-out of academic activities and therefore, their engagement in facilitating performance outcomes cannot be ignored. This yield useful insight in that strategies for enhancing universities' efficiency need changes in the management culture and mindset. This notion draws attention to the importance of accounting for non-academic staff in assessing efficiency of universities. In this context, we argue that if academic staff are assumed to dominate the efficiency of South African public universities while the effort of non-academic staff is not considered, a biased conclusion on the subject matter is likely. The current study is, therefore, conducted in response to this gap and seeks to make an assessment of efficiency of South African public universities with both academic and non-academic staff included as input variables.

In addition to the aforementioned empirical contribution, this article also evaluates Pure Technical Efficiency (PTE) and Scale Efficiency (SE) among 23 public South African universities with the aim of allowing policy makers or education stakeholders to know the efficiency levels of universities and determine the target levels for institutions that are inefficient and improvements required to reach a satisfactory level of efficiency. Measuring 
efficiencies in institutions would be recognised as one of the steps in monitoring and evaluation of public sector universities (Cunha and Rocha 2012).

The next section provides an overview of HE in South Africa, followed by a review of the literature. This will be followed by a discussion of the DEA methodology that will be used to evaluate the TE, PTE and SE of public South African universities, and a discussion of the results and observations made.

\section{OVERVIEW OF HIGHER EDUCATION IN SOUTH AFRICA}

HE in South Africa is divided into public universities, private universities and colleges of further education and training. Public universities and colleges of further education and training are mainly funded by government. According to the 2011 Census (Statistics South Africa 2012), South Africa has a population of about 51.8 million, 79.2 per cent of whom are Black Africans, followed by Whites and Coloureds which each constitute 8.9 per cent, with Indians or Asians constituting only 2.5 per cent of the population. In South Africa 62.9 per cent of the population is urban, followed by traditional areas with 31.8 per cent and farms with 5.3 per cent. The apartheid history in South Africa left HE deeply marked by discrimination and authoritarian legacy (DHET 2015), especially for Black Africans who are the majority in the country. The public universities accept students from poor backgrounds since government supports these students through NSFAS. Therefore, it was important to concentrate on public universities which fall under HE, since they are mainly funded by government.

In 1994, the post-apartheid government aimed at transforming HE which during apartheid saw universities separated on a racial basis, and access for students to funding, resources and infrastructure was mainly dependent on racial background (Kotecha, Wilson-Strydom, and Fongwa 2012). The main emphasis on transforming HE in South Africa was to ensure access for the previously disadvantaged, represented mainly by the Black population. Therefore, HE in South Africa in terms of economic level seeks to redress the skills divide that resulted in fragmented HE.

Post-apartheid, the fragmented and structurally racialized system of 36 public universities were merged into 26 universities which were classified into three broad categories and 95 private HEIs in 2015 (DHET 2015). In terms of qualification types, HE has become more unified with a well organised single qualifications system designed to provide consistency for degree and diploma purposes (Council on Higher Education 2016). There has been a dramatic increase in the number of students entering universities in South Africa, especially Black Africans who were previously denied access. Since the growth has not been met with adequate funding, public HEIs have not been able to accomplish their objectives and government funding 
has increased only marginally (Council on Higher Education 2016).

In the South African, decreasing state funding (in real terms) has occurred at a time when the HE sector is in greater need of state financial support with increase in the access to HE (HESA 2008). In real terms, state support for higher education has decreased (1.1\% from 2000 to 2012), while the amount of gross domestic product (GDP) allocated to HE has remained around 0.7 per cent, which is very low relative to international standards (Langa et al. 2016).

To finance HE the government in South Africa adopted a cost-sharing model between the state and the beneficiaries of consuming HE (Johnstone 2006). An individual needs to pay more towards their fees due to the fact that more benefits accrue to an individual: but cost sharing is a main challenge in South Africa due to the high rates of poverty that characterise this economy. Tuition fees are a major inhibiting factor, making it difficult for many students to attain HE. Therefore, the government in SA subsidises the costs of students through financial aid schemes to assist deserving and needy poor students to meet their demands to have access to HE. Evaluating the efficiency of HEIs will be important because if the sector operates efficiently, it will free some funds to help fund many students who enter the system. Based on these factors efficient universities will attract better students due to better infrastructure and more resources than inefficient universities.

\section{LITERATURE REVIEW}

This section is divided into theoretical and empirical evidence linked to the efficiency evaluation of HEIs.

\section{Review of theoretical literature}

The efficiency proposition of HEIs is widely derived from the production or the producer theory (Myeki and Temoso 2019). The economic theory of producer behaviour is used in the study as a framework to explain how HEIs transform various inputs into various outputs. Emrouznejad and Cabanda (2015) define production as a process that transforms inputs such as land, labour, capital and entrepreneurship into outputs. Therefore, the underlying issue of efficiency that converts inputs into outputs can be measured by efficiency. HEIs are treated as Decision Making Units (DMUs) that transform multiple inputs into multiple outputs through a transformation function "black box" as widely used in data envelopment literature (Emrouznejad and Cabanda 2015).

Production theory shows that the main objective of a production unit is to maximise the output given a set of inputs (Levin and Milgrom 2004). These authors argue that HEIs are quasipublic entities with multiple objectives to transform society through educating individuals for better jobs and developing society through research which brings innovation to the economy. 
Therefore, objectives of HEIs are to pursue both economic and social objectives. This model might not follow the standard neoclassical theory of production of assuming an organisation's main objective is to maximise profit or minimise costs, however, this can be used in the case of HEIs as they seek to maximise the number of graduates and research outputs subject to resource availability and given operating environments. Given the theoretical framework of the producer theory, the context of our study uses multiple inputs and outputs which becomes a constrained optimisation problem. In the view of Johnes and Tone (2017), DEA is very useful in cases where a multiplicity of inputs is used to produce a multiplicity of outputs, and where market prices are not available.

\section{Review of empirical literature}

The theoretical framework above assisted in understanding the efficiency evaluation framework of HEIs using a non-parametric approach (DEA). The DEA model has been used since the 1980s to assess the efficiency of different sectors of the economy (Wolszczak-Derlacz 2014). Most studies on efficiency analysis in HE have concentrated on developed counties, with limited studies on developing countries especially in Africa and more specifically in South Africa. The DEA methodology was developed by Farrell (1957) and Charnes et al. (1978). Later Johnes and Johnes (1993) employed a non-parametric method for the academic year 1989 in economics departments in 36 universities in the UK. They were followed by Coelli (1996), who employed a DEA model using Variable Returns to Scale (VRS) to 36 Australian universities in calculating both technical and scale efficiencies of universities. Madden, Savage and Kemp (1997) investigated the economics departments of 24 Australian universities for the period 1987-1991. Since then, there has been a growing trend concerning efficiency of HEIs but, as mentioned above, research has concentrated on developed countries.

In developing countries, particularly in Africa, empirical studies of this subject matter is still scant. Bangi and Sahay (2014) assessed the TE of private universities in Tanzania using a two-stage DEA approach for the period 2008-2012. They found an average TE score of 0.93 indicating 7 per cent potential to improve performance outcomes. In the South African context, Taylor and Harris (2004) evaluated the efficiency of a sample of 10 South African public universities using DEA and concluded that maintaining graduate output enhances universities' efficiency levels. In essence, Taylor and Harris (2004) found that the rates of graduation in some universities were partly driven by the general quality of the academic staff and increase in fixed cost was found to be a threat to efficiency of the universities. More recently, Myeki and Temoso (2019) employed DEA to examine the efficiency of 22 South African public universities for the period 2009-2013. They found that the average TE score for these universities decreased from 83 per cent to 78 per cent over their study period. 
While the study of Myeki and Temoso (2019) lays the groundwork for an assessment of efficiency of HEIs in South Africa, it neglected non-academic staff as an input variable to evaluate efficiency of South African public universities. Non-academic staff are involved in soliciting funding with relevant stakeholders while others provide administration and general work. Baltaru (2019) asserts that non-academic staff ensure the smooth roll-out of academic activities and therefore, their engagement in facilitating performance outcomes cannot be ignored. Myeki and Temoso's (2019) study yields useful insight in that strategies for enhancing universities' efficiency need changes in the management culture and mindset. This notion draws attention to the importance of accounting for non-academic staff in assessing efficiency of universities. In this context, we argue that if academic staff are assumed to dominate the efficiency of South African public universities while the effort of non-academic staff is not considered, a biased conclusion on the subject matter is likely. The current study is, therefore, conducted in response to this gap and seeks to make an assessment of efficiency of South African public universities with both academic and non-academic staff included as input variables among others.

Despite the limitation highlighted above, in the South Africa context, the fundamentals of the literature in HE are formed by these two studies (Taylor and Harris 2004; Myeki and Temoso 2019) although we do not disregard the contribution of other studies. The empirical investigations by Taylor and Harris (2004) and Myeki and Temoso (2019) prove that DEA can contribute positively to the development of performance indicators of public universities in South Africa. Therefore, the analysis of HEI's efficiency was built based on their theoretical and methodological framework.

\section{Application of DEA}

In applying DEA successfully when estimating the efficiency frontier, measurement of inputs and outputs is needed. There are differing views on how to measure and quantify inputs and outputs since many of these variables do not have market prices (Srairi 2014). Moreover, establishing a direct relationship between inputs and outputs is difficult when measuring education efficiency (Bangi and Sahay 2014). When determining efficiency of HEIs a proximal relationship is applied, for example total enrolment of students cannot be the only variable that leads to graduation in $\mathrm{HE}$, there are numerous contributing factors. Therefore, according to Srairi (2014), selection of outputs does not have definite standards to follow. The objectives of universities, according to international logic, is to teach and research, therefore the number of graduated students and number of published papers are quantified as results (Adamu, Soon, and Ahmad 2016).

Apart from Taylor and Harris (2004) and Myeki and Temoso (2019), other studies which 
proxy for outputs as number of graduates and published papers for evaluating efficiency of universities include Andersson et al. (2017), Marire (2017), Duan and Deng (2016), Erkoç (2016), Bangi and Sahay (2014), Wolszczak-Derlacz (2014), Al-Bagoury (2013) and Agasisti and Johnes (2010).

Input variables of HE are considered less controversial than how they should be quantified (Srairi 2014). Input variables of HEIs are generally agreed as human and physical capital (for example academic and non-academic staff, number of students, library buildings, computers etc.).

In the next section, non-parametric DEA model is presented. This model was utilised to assess technical efficiency, pure efficiency and scale efficiency in the South African public universities.

\section{METHODOLOGY}

\section{Analytical technique}

DEA is a non-parametric technique derived from the work of Farrell (1957) and Charnes et al. (1978). It uses mathematical programming techniques or linear programming techniques to evaluate the production possibility frontier and analyse the technical efficiency of each decision-making unit (DMU) in relation to the frontier (Johnes and Johnes 1993).

While we follow Myeki and Temoso (2019) in assessing efficiency of South African public universities utilising DEA, the model is widely lauded for its ability to examine the relative efficiency of DMUs producing multiple outputs through the use of multiple inputs where the underlying production relationship is not well understood (Selim and Bursalığlu 2015). This in line with the study of Duan and Deng (2016) which argues that DEA can account for multiple input and multiple output models. Further, DEA model does not need an assumption of a functional form relating inputs to outputs as in parametric models (Yuangyai 2017). Therefore, the efficiency identified using DEA is directly observable since other institutions would have already demonstrated that higher levels of efficiency can be achieved. These advantages favour our data and sample, therefore, making DEA a relevant model to adopt. However, Adamu et al. (2016) argue that since DEA is a non-parametric model, when a large number of DMUs are involved statistical hypothesis tests becomes intensive and difficult, hence we restricted our input variables to four. Moreover, DEA can only measure efficiencies of DMUs at a specific time and cannot account for changes across time (Yuangyai 2017). To account for this weakness, we measured efficiency on annual basis rather than taking the entire study period.

The DEA model generally is an operationalised non-parametric model that is either input- 
or output-orientated: an input-orientated approach evaluates the ability to minimise inputs while keeping output fixed, while an output-orientated approach evaluates the ability to optimise outputs of the DMU assuming fixed inputs (Selim and Bursalığlu 2015). The main characteristic of the DEA approach is to transform multiple input-output DMUs into a single input-output value for all DMUs. The DEA model is appropriate in assessing the efficiency of a university because it is able to handle inputs and outputs simultaneously (Duan and Deng 2016). DEA calculates the maximum efficiency measure for each DMU in relation to other DMUs, therefore the technical efficiency measure provided is the ratio of output to input. The DMUs that do not lie on the frontier are said to be inefficient and these are measured against those that lie on the frontier. It is essential to note that the aim of DEA analysis is not only to determine efficiency but also to find the target values for input and output for inefficient units. In order to understand the DEA model, let us consider the case of public South African universities which uses input vector $x=\left(x_{1}, \ldots, x_{N}\right) \in R_{+}^{N}$ to produce output vector = $\left(y_{1}, \ldots, y_{M}\right) \in R_{+}^{M}$. Therefore, the production possibility set is presented by the production set:

$$
T=\left\{(x, y): \in R_{+}^{M+N} x \text { can produce } y\right\}
$$

We assume that outputs will be proportionally increased while the input proportions remain unchanged. For this study the output orientation DEA model based on VRS proposed by Banker, Charnes and Cooper (1984) (BBC model) will be adopted as this requires all DMUs to operate optimally (Duan and Deng 2016). The output orientation model will be appropriate for HE since the principle of cost minimisation is not applied according to market conditions (Adamu et al. 2016). In applying the DEA model the choice of assumption between Constant Returns to Scale (CRS) and VRS needs to be made. In the real world, choosing the CRS assumption might lead to misleading results of technical efficiency due to different circumstances faced by universities such as constraints on finances, imperfect competition, etc. (Yuangyai 2017). Therefore, the output orientation BBC model will be specified as follows:

$$
\max _{\theta_{k}, \lambda} \theta_{k}
$$

Subject to:

$$
\begin{array}{ll}
\sum_{k=1}^{s} Y \lambda_{k} \geq \theta y_{i k}, & i=1, \ldots, m \\
\sum_{k=1}^{s} X \lambda_{k} \leq x_{j k}, & j=1, \ldots, n \\
\sum_{k=1}^{s} \lambda_{k}=1 & \lambda \geq 0
\end{array}
$$

The $\max _{\theta_{k}, \lambda} \theta_{k}$ represents the relative efficiency of universities to be maximised, which yields an 
efficiency rating that measures the distance to the efficiency frontier. The objective $\sum_{k=1}^{S} Y \lambda_{k} \geq \theta y_{i k}$ represents maximising output, while $\sum_{k=1}^{S} X \lambda_{k} \leq x_{j k}$ represents a constraint of using given resources. The expression $\theta_{k}$ will be the maximised efficiency and the expression $x_{j k}$ defines the amount of $j^{\text {th }}$ input that will be used by the $k^{\text {th }}$ university. The outputs are given by $y_{i k}$ for the $i^{\text {th }}$ output of the $k^{\text {th }}$ university where $\mathrm{K}=1 \ldots, 23$ represents universities.

$1 \leq \theta_{k} \leq \infty$, and $\theta$ is the proportional increase in output that may be achieved by the $k^{t h}$ university, when holding input constant. Therefore, the TE score can be defined by $1 / \theta$ which varies between zero and one.

In estimating scale efficiency, we imposed another restriction in equation (2) $\sum_{k=1}^{s} \lambda_{k} \leq$ 1 to estimate SE by computing TE under CRS as expressed below:

$S E=\frac{T E_{C R S}}{T E_{V R S}}=\frac{\text { Technical Ef ficiency of University }}{\text { Pure Technical Efficiency of University }}$

Therefore, the TE or overall efficiency can be decomposed into the following:

$$
\left[\begin{array}{c}
\text { Technical } \\
\text { Efficiency }(T E)
\end{array}\right]=\left[\begin{array}{c}
\text { Pure Technical } \\
\text { Efficiency }(P T E)
\end{array}\right] *\left[\begin{array}{c}
\text { Scale } \\
\text { Efficiency }(S E)
\end{array}\right]
$$

This measurement is obtained from each university by conducting both CRS and VRS DEA and decomposing the TE scores obtained from the CRS DEA into two components, one of which will be due to SE and the other to PTE. The SE measurement can be simply interpreted as the link between the output level and the average cost, consequently it relates to the size of the operation within the organization (Marwa and Aziakpono 2016). The decomposition of TE describes the sources of inefficiencies such as inefficiencies due to inefficient operation (PTE) or inefficiencies due to operating scale inefficiency (Abel and Bara 2017).

The above SE measurement is insufficient to determine whether a particular DMU is operating in an area of increasing, decreasing or constant returns to scale. The drawback of SE can be addressed by estimating an additional DEA model with a Non-Increasing Return to Scale (NIRS) imposing the following restriction $\left[\sum \lambda j n j=1 \geq 1\right]$ in equation (2) (Coelli et al. 2005).

\section{Data and variables}

Evaluating efficiency of public South African universities, the data used in the study is sourced from the Centre of Higher Education and Trust (CHET), Department of Higher Education and Training (DHET) and Higher Education Data Analyser (HEDA) portals over the period 2009 
to 2016. The study looks at 23 public South African universities after the universities merged with technikons during 2001-2007, and categorised into 11 traditional universities, 6 universities of technology (formerly technikons) and 6 comprehensive universities (which offer both technikon and university type programmes) (Arnolds, Lillah, and Stofile 2013). The study looks at the universities that have existed for more than five years. In all, four inputs and two outputs are nominated based on frontier efficiency literature in HEIs and availability of data. Table 1 provides input and output variables for the evaluation of TE for public South African universities for this study.

Table 1: Input and output variables for evaluating technical efficiency

\begin{tabular}{|c|c|}
\hline Input Variables & Output Variables \\
\hline 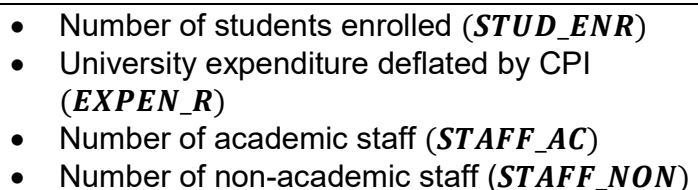 & $\begin{array}{l}\text { - Weighted graduates (GRAD) } \\
\text { - Total research outputs (published journals, books, } \\
\text { masters, doctoral and post-doctoral dissertations) }\end{array}$ \\
\hline
\end{tabular}

\section{RESULTS AND DISCUSSION}

Table 2 shows the descriptive statistics (mean, minimum, maximum, standard deviation) for the period 2009 to 2016 for research output, number of graduates, student enrolment, university expenditure, academic staff and non-academic staff. Based on the summary statistics the number of students enrolled in public South African universities is on average around 40,882. The highest enrolment of students is around 355,240 and the minimum is around 7,012. Student enrolment in public universities has raised, especially the black majority. On average South African public universities spend in real terms R379,559.9 million: the maximum real expenditure is $\mathrm{R} 1,357,940$ million and minimum real expenditure is $\mathrm{R} 48,111.6$ million. The main contributor to the total expenditure of universities is compensation of employees which accounts for around 61 per cent of the total budget, followed by purchases of goods and services which accounts for 33 per cent (Statistics South Africa 2018). Universities on average have 761 academic staff compared to an average of 1,381 non-academic staff. Therefore, there are nearly twice as many non-academic staff as academic staff. The number of graduates from South African public universities is on average around 6,763 for the period under review and the number of publications is on average around 911 for the same period. The university with the highest number of students enrolled was UNISA and the university with lowest number of students enrolled was RU. The top three universities with highest number of students graduating were UP, SU and UCT which shows that traditional universities produce more students graduating than the other two categories of university. Even though there are more students 
entering public universities, there is a concern that the number of students leaving with the qualification is low.

Table 2 shows an Analysis of Variance (ANOVA) which analyses the differences of means across groups. To conduct this test for the context of public South African universities is important as universities are categorised into three different groups. ${ }^{2}$ South African Public universities might be affected with the merging of some universities while other universities remained unchanged. South Africa's public universities experienced unprecedented student demonstrations in 2015 due to historical moments in HE in the period under investigation.

The protests quickly gained momentum and became a national student uprising demanding for free education and HE decolonization. Most of the universities were forced to stop academic activities, the protest resulted in damage of valuable university infrastructure which costed hundreds of millions of rands and led to violent clashes between students and law enforcement agency.

The F-statistics of a one-way Anova test was conducted to check whether there was any statistically significant difference of variables across time, and the results revealed no significant differences across time. The F-statistics of the one-way Anova test conducted to check for difference of variables across categories, revealed significant differences in the dataset for categories of universities. This shows that university categories are an important factor as they can affect the results of efficiency in universities.

Table 2: Summary statistics of variables used (Pooled)

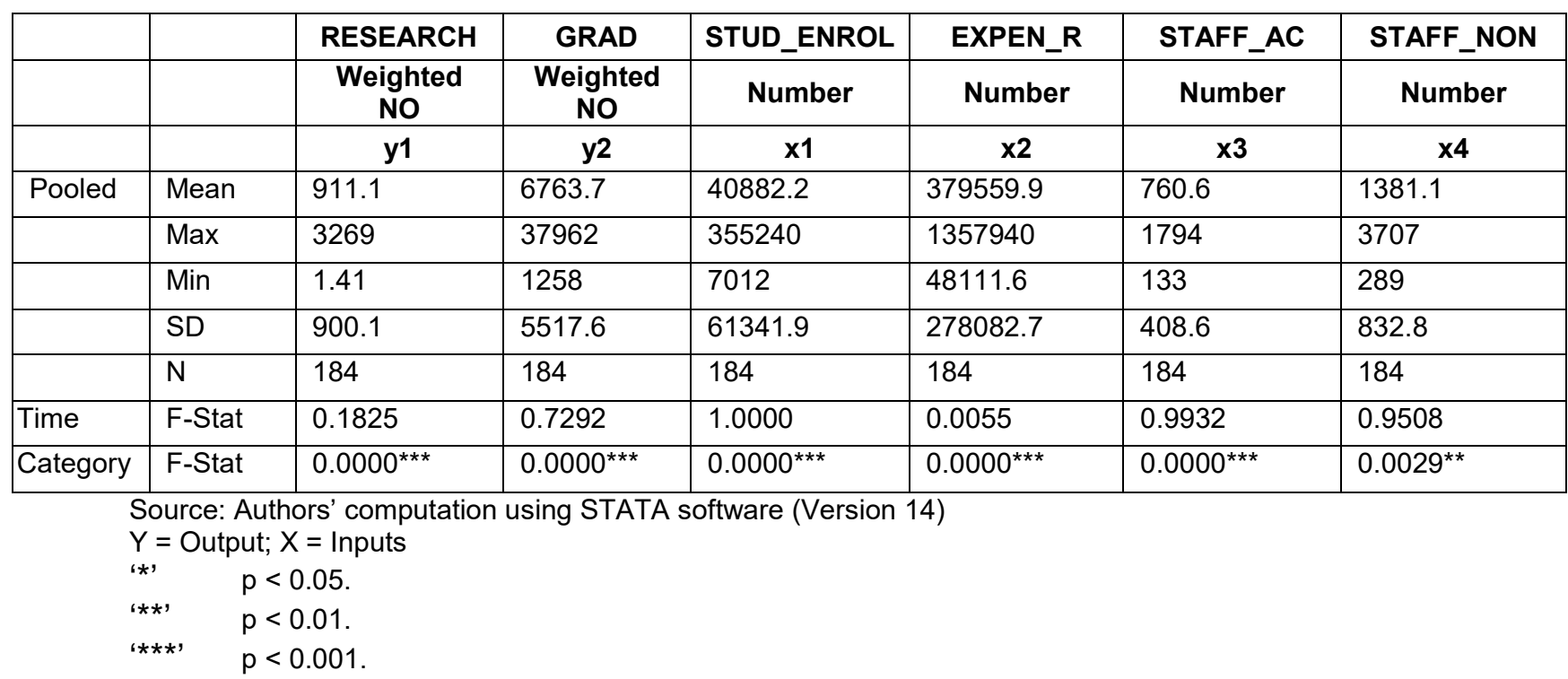

The DEA model for 23 South African public universities for the academic years 2009 to 2016 was used to evaluate the average TE, PTE, SE and Return to Scale (RTS) classification using 
output-oriented approached results which are summarised in Table 3 and in tables in the appendix. Relative efficiencies were estimated using the STATA 14 software where public South African universities are randomly used and represented by $\mathrm{DMU}_{1}$ to $\mathrm{DMU}_{23}$. The desirable situation for South African public universities would be to see these universities closer to one to be operating efficiently for TE, PTE and SE, whereas for RTS the desirable situation is having many universities experiencing constant returns to scale.

A university is said to be TE if it produces the maximum number of outputs with minimum inputs relative to its peers, subject to limited resources and the environment under which it operates. TE can be decomposed to PTE and SE and this will assist in determining the main sources of inefficiencies in universities. PTE measures how universities use their resources to produce maximum output under the external environment, whereas SE measures whether universities are operating at their optimal scale. RTS assists in determining whether universities are operating at the most productive scale (CRS), increasing RTS and decreasing RTS. The performance ranking reported in the study is based on the TE.

Table 3 and Tables 8, 9 and 10 in the appendix shows the efficiency scores for TE, PTE and SE for 23 South African public universities. The results showed that South African public universities were technically efficient with an average TE score of 0.9346 during the period 2009-2016. This result implies that the average South African public universities suffered a 6.5 percent level of technical inefficiency. The results of technical efficiency also revealed that out of 23 South African public universities only four universities in South Africa that were fully efficiency (NWU, UP, RU and SU) throughout the period under investigation, while those that were consistently inefficient during the eight years of academic observation were FS, MUT, UWC and WSU. These results were consistent with the results of Myeki and Temoso (2019), which also revealed that RU and SU were fully efficient throughout the period 2009-2013. Myeki and Temoso's (2019) results revealed that universities that were fully efficient were UCT, UFS, RU and SU for the period 2009-2013 using input-oriented VRS DEA model.

The results show that on average PTE of the South African public universities for the period 2009 to 2016 was 0.9603 . The pure technical efficiency score was not stable but showed a decline in 2010, an increase in 2011 and a decrease again in 2012, followed by an increase in 2013 to 2015 then a further decrease in 2016. The results for pure technical efficiency scores revealed that that out of 23 universities, eleven universities (CPUT, CUT, DUT, UJ, NWU, UP, RU, UNISA, SU, TUT and MUT) were found to be lying on the efficient frontier for the academic years 2009-2016, which indicated that these universities fully use their resources efficiently in fulfilling the objective of teaching and research and are relatively more efficient than the others. The limitation of the DEA model is in explaining why differences occur. Taylor 
and Harris (2004) explain this using the contingency theory, which says that organisations are influenced by the environment, history, and factors such as size of the organisation, stability of the environment, the personalities involved at all levels of operations, leadership of the entity and the competitiveness of the market. There can be some differences which make some universities more successful and relatively more efficient than others. However, those that were consistently inefficient during the eight years of academic observation were UWC and WSU. The average PTE for the eight academic years has declined from 0.978 in 2009 to 0.945 in 2010, increasing in 2011 to 2012, remained constant in the following year and continued to increase afterwards.

The results in Table 3 and in Table 10 in the appendix show that the average scale efficiency scores of South African public universities for the period 2009-2016 was 0.9731. The scale efficiency scores were not stable as can be seen from the increase experienced for the period 2009-2011, followed by a decrease in 2012, an increase in 2013 before further declining in 2014 to 2016. The results of scale efficiency also revealed that out of 23 South African public universities only four were fully efficiency (NWU, UP, RU and SU) throughout the period under investigation.

Table 3: Mean of TE, PTE and SE of public South African universities

\begin{tabular}{|l|c|c|c|c|}
\hline University & DMU & CRS_TE_MEAN & VRS_TE_MEAN & SCALE_MEAN \\
\hline CPUT & 1 & 0.9961 & 1.0000 & 0.9961 \\
\hline UCT & 2 & 0.9820 & 0.9934 & 0.9880 \\
\hline CUT & 3 & 0.9714 & 1.0000 & 0.9714 \\
\hline DUT & 4 & 0.9989 & 1.0000 & 0.9989 \\
\hline FH & 5 & 0.9193 & 0.9951 & 0.9235 \\
\hline FS & 6 & 0.9544 & 0.9587 & 0.9954 \\
\hline UJ & 7 & 0.9740 & 1.0000 & 0.9740 \\
\hline KZN & 8 & 0.9327 & 0.9728 & 0.9573 \\
\hline UL & 9 & 0.8030 & 0.8110 & 0.9891 \\
\hline NMU & 10 & 0.9328 & 0.9395 & 0.9927 \\
\hline NWU & 11 & 1.0000 & 1.0000 & 1.0000 \\
\hline UP & 12 & 1.0000 & 1.0000 & 1.0000 \\
\hline RU & 13 & 1.0000 & 1.0000 & 1.0000 \\
\hline UNISA & 14 & 0.9910 & 1.0000 & 0.9910 \\
\hline SU & 15 & 1.0000 & 1.0000 & 1.0000 \\
\hline TUT & 16 & 0.9819 & 1.0000 & 0.9819 \\
\hline UNIVEN & 17 & 0.7974 & 0.8761 & 0.9098 \\
\hline VUT & 18 & 0.9255 & 0.9439 & 0.9800 \\
\hline WSU & 19 & 0.7137 & 0.7210 & 0.9899 \\
\hline UWC & 20 & 0.9052 & 0.9333 & 0.9696 \\
\hline WITS & 21 & 0.9412 & 0.9552 & 0.9858 \\
\hline UZ & 22 & 0.9370 & 0.9872 & 0.9481 \\
\hline MUT & 23 & 0.8384 & 1.0000 & 0.8384 \\
\hline \multicolumn{2}{|l}{ Average } & 0.9346 & 0.9603 & 0.9731 \\
\hline
\end{tabular}


Based on the results in Table 3 and Tables 8,9 and 10 in the appendix, the source of the technical inefficiency of public South African universities is PTE rather than SE. The results mean that universities are mostly suffering from the managerial efficiency.

Table 4 indicates the results of the pulled sample size for average scores for TE, PTE and SE. The total number of results is 184 , which represents 23 South African public universities over 8 years. This was done in order to have a larger sample size, such that each university is measured at a particular point rather than being treated as a single data point. Therefore, within the analysis we have 184 results for the period 2009-2016 which will make our results robust. The results reveal that 87 universities were fully efficient (had a score of 100\% under TE), 124 universities had a score of 100 per cent under PTE, and 87 universities had a score of 100 per cent under SE for the period 2009-2016. Table 4 also shows the distribution of universities across constant returns to scale (CRS-optimal scale), increasing returns to scale (IRS) - too small, and decreasing returns to scale (DRS) - too large. The results reveal that about 87 universities out of $184(47.3 \%)$ were operating at optimal level, 28 out of $184(15.2 \%)$ were operating at sub-optimal level, and 69 out of 184 (37.5\%) were operating below the optimal level. From the managerial perspective this implies that universities that are operating beneath the optimal scale may need to scale up and those universities operating above their optimal scale may need to improve their performance by scaling down.

Table 4: Summary of Efficiency Estimate with total number of DMUs

\begin{tabular}{|l|l|l|}
\hline \multicolumn{2}{|l|}{ Item } & Estimates \\
\hline Number of DMUs & $184^{3}$ \\
\hline Number of Efficiency DM under & CRS_TE & 87 \\
& VRS_TE & 124 \\
\cline { 2 - 3 } & SCALE & 87 \\
\hline \multirow{4}{*}{ Average } & CRS_TE & 0.9346 \\
\cline { 2 - 3 } & VRS_TE & 0.9603 \\
\cline { 2 - 3 } & SCALE & 0.9731 \\
\hline \multirow{3}{*}{ Return to Scale } & CRS & $47.3 \%(87)$ \\
\cline { 2 - 2 } & DRS & $37.5 \%(69)$ \\
\cline { 2 - 2 } & IRS & \\
\hline
\end{tabular}

Note: Constant Returns to Scale (CRS), Decreasing Returns to Scale (DRS) and Increasing Returns to Scale (IRS)

Table 5 demonstrates that efficiency scores have been tested to determine whether they differ substantially from 1and the all the three efficiency measures have been found to be significantly below 1. This means that the universities is on average below the desired level of efficiency as shown by the negative and significant test statistics based on both one sample t test and one sample Wilcoxon signed rank test approach. TE scores are decomposed into PTE and SE in an 
effort to understand the sources of inefficiencies. When the scale of $t$ statistics is compared, SE appears to be on average better than PTE. This is consistent to the results presented in Table 4, with average scores of 94 per cent, 96 per cent and 97 per cent for TE, PTE and SE respectively. This means that most of the inefficiency is contributed by managerial efficiencies in universities.

Table 5: Parameter Estimates for Testing Efficiency Scores are different from 1

\begin{tabular}{|l|l|l|l|l|}
\hline \multicolumn{3}{|c|}{ T test (one sample) } & \multicolumn{2}{c|}{ Wilcoxon Signed Rank Text } \\
\hline Variables & Test Statistics & P-value & Test Statistics & P-value \\
\hline TE_CRS & -9.177 & $<0.0000$ & -9.647 & $<0.0000$ \\
\hline TE_VRS & -6.489 & $<0.0000$ & -7.698 & $<0.0000$ \\
\hline SCALE & -7.130 & $<0.0000$ & -9.647 & $<0.0000$ \\
\hline
\end{tabular}

Note: The left hand panel of the table represents one sample T-test results for different mean efficiency scores for SA universities and the right hand panel of the table represents one sample Wilcoxon Signed Rank Test of mean efficiency scores for SA universities

Based on the box plot and the results in Tables 3 and 4, most of the inefficiencies emanate from PTE rather than SE. The wide spread of the box plot is an indication that there is a potential for significant spread of managerial competencies and quality across universities.

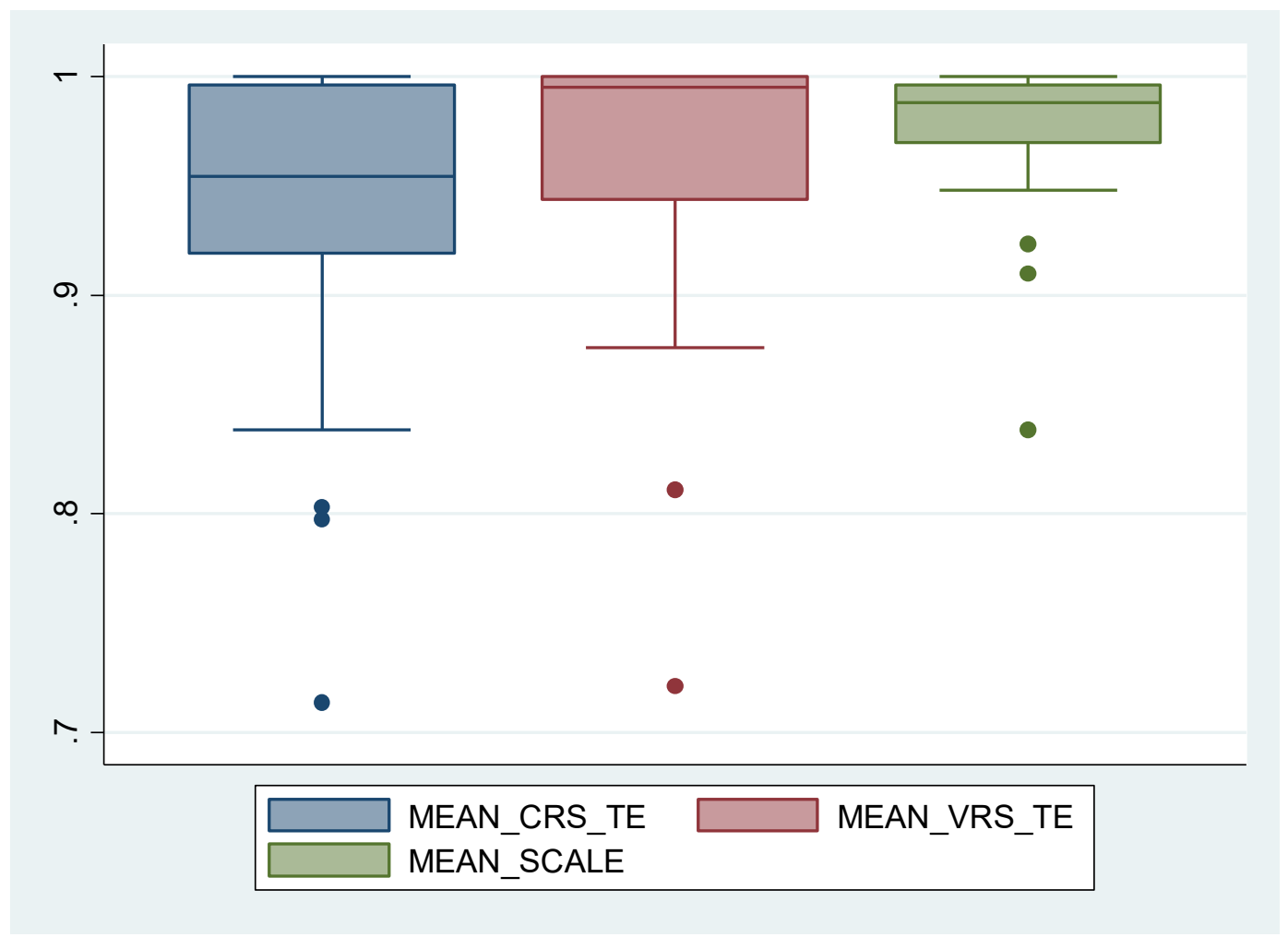

Figure 1: Box plot for Mean Technical efficiency CRS, Mean Technical efficiency VRS and Scale efficiency scores across universities in South Africa

Tables 12 and 13 in the appendix show the value and the reference of the universities that should 
improve efficiency performance, presented by the summary of peers. The percentage variation indicates the peer weights in order to adopt the trend of the reference university to become efficient. The peer count indicates the number of times an efficient university acts as a reference for inefficient universities. In 2009 the following universities FH, FS, KZN, UL, NMU, UNIVEN, VUT, WSU, UWC, WITS, UZ and MUT refer to the following universities: CPUT, CUT, DUT, NWU, RU, SU, TUT and UP to become effective for output-oriented VRS-DEA. The top three universities to be used as a benchmark to improve universities' performance were CPUT, RU and NWU. The results are consistent with Myeki and Temoso (2019): the following universities KZN, UL, NMU, UNIVEN, WSU, UWC and UZ should refer to universities RU, SU and NWU to improve performance.

In 2016 the following universities UCT, CUT, FS, UJ, NMU, UNIVEN, VUT, WSU, UWC and MUT should refer to the following universities: DUT, FH, NWU, RU, SU, UL, UNISA, UP, UZ and WITS to become effective for output-oriented VRS-DEA. The top three universities to be used as benchmarks to improve universities' performance were DUT, SU and UNISA.

Our findings show that that over the study period 2009-2016 the average TE of the South African public universities increased from 91 per cent to 95 per cent. Precisely, our findings illustrate that the average TE score was constant at 91 per cent for the period 2009-2010 then increased to 94 per cent in 2011 and remained constant at 95 per cent for the period 2012-2012. Conversely, Myeki and Temoso (2019) found a decline in the average TE score of the South African public universities from 83 per cent in 2009 to 78 per cent in 2013. It is also vital to note that our estimated average TE scores are significantly higher than those obtained by Myeki and Temoso (2019). In light of this outcome, we can argue that omitting non-academic staff as an input variable tends to understate the average TE score of South Africa public universities. Accordingly, this validates our argument that both academic and non-academic staff are vital input variables for determining performance outcomes of South African public universities. Although a significant magnitude exits between our estimated average TE scores and those obtained by Myeki and Temoso (2019), both studies show high TE scores of public universities in South Africa.

\section{CONCLUSION}

This study investigated the technical efficiency of 23 South African public universities. The data used was collected from CHET, DHET and HEDA portals over the period 2009-2016. An output-oriented approached was used within a DEA framework to estimate efficiency scores of South African public universities in terms of TE, PTE and SE. The empirical results indicate 
that the average TE is about 94 per cent, average PTE was 96 per cent, and SE was 97 per cent. Based on the average TE estimate and in view of the findings obtained by Myeki and Temoso (2019), we can deduce that academic and non-academic staff complement each other to facilitate performance outcomes of public universities in South Africa. In assessing efficiency of South African public universities, the variables can be deemed as mutually inclusive, and therefore omitting either of the two can lead to biased estimated average TE scores.

Most public universities are struggling with how to efficiently utilise their resources to maximise their output, this is shown by the fact that only four South African public universities (NWU, UP, RU and SU) out of 23 were TE throughout the period under investigation, while those that were consistently technical inefficient in the same period were FS, MUT, UWC and WSU. The results revealed that the source of the technical inefficiency of the public South African Universities is the pure technical efficiency instead of scale efficiency which means South African public universities are mostly suffering from the managerial efficiency. The study also provided universities that could be used as targets or role models to improve their efficiency for those universities that are inefficient. In 2009 the top universities to be used as benchmark were RU, SU and NWU, while in 2016 the top universities to be used as benchmarks were DUT, SU and UNISA.

The policy implication from our study relates to management of universities. Public universities across South Africa need to improve managerial competencies and also improve capacity within management for better performance. The South African government should expand support to public universities by providing additional educational support to students who do not have the necessary skills to succeed in universities: for example, some students may require an additional foundation year.

Future studies may wish to analyse the impact of other factors that might affect efficiency and productivity changes of efficiency over time using the DEA Malmquist Productivity Index (MPI). This will help to explain other factors that might be important in explaining the impact on efficiency. Including data for the infrastructure of universities and socio-economic factors might also help to explain how the efficiency of public universities will be affected if such variables are included in the model.

\section{ACKNOWLEDGEMENTS}

The research for this article was supported financially by the National Institute for the Humanities and Social Science (NIHSS) (2 ${ }^{\text {nd }}$ floor, 24 St Andrews Johannesburg, Parktown, Gauteng, 2193). 


\section{NOTES}

1. Paper presented at The Economic Society of South Africa conference, 3-5 September 2019, Johannesburg

2. Traditional university, comprehensive university and university of technology.

3. The results for 23 South African public universities over eight years were pulled together, giving a total of 184 universities ( 23 universities multiplied by 8 years).

\section{REFERENCES}

Abel, S. and A. Bara. 2017. "Decomposition of the technical efficiency: Pure technical and scale efficiency of the financial systems." Working Papers 683. Economic Research Southern Africa.

Adamu, M., J.-J. Soon, and S. A. Ahmad. 2016. "An empirical investigation into the technical efficiency of public universities in Nigeria through a non-parametric technique." International Journal of Current Research 8(12): 44075-44080.

Agasisti, T. and G. Johnes. 2010. "Heterogeneity and the evaluation of efficiency: The case of Italian universities." Applied Economics 42(11): 1365-1375.

Ahmad, A. R., A. Farley, and M. Naidoo. 2012. Impact of the government funding reforms on the teaching and learning of Malaysian public universities. Higher Education Studies 2(2): 114-124.

Aigner, D. J., C. Lovell, and P. Schmidt. 1977. "Formulation and estimation of stochastic frontier production function models." Journal of Econometrics 6(1): 21-37.

Akor, E. U. and N. L. Roux. 2006. "State of higher education funding in South Africa: Policy implications for institutional autonomy and academic freedom." Journal of Public Administration 41(2.2): 422-433.

Al-Bagoury, S. 2013. "Using DEA to evaluate efficiency of African Higher Education." Educational Research 4(11): 742-747.

Allais, S. 2017. "Towards measuring the economic value of higher education: lessons from South Africa." Comparative Education 53(1): 147-163.

Andersson, C., J. Antelius, J. Månsson, and K. Sund. 2017. "Technical efficiency and productivity for higher education institutions in Sweden." Scandinavian Journal of Educational Research 61(2): 205-223.

Arnolds, C. A., R. Lillah, and R. N. Stofile. 2013. "Assessing the outcomes of higher education mergers in South Africa: Implications for strategic management." Acta Commercii 13(1): 1-11. Art \#175. https://dx.doi.org/10.4102/ac.v13i1.175.

Baltaru, R. D. 2019. "Do non-academic professionals enhance universities' performance? Reputation vs. organisation." Studies in Higher Education 44(7): 1183-1196.

Bangi, Y. and A. Sahay. 2014. "Efficiency of the Tanzanian universities." Journal of Education and Practice 5(14): 130-143.

Banker, R. D., A. Charnes, and W. W. Cooper. 1984. "Some models for estimating technical and scale inefficiencies in data envelopment analysis." Management Science 30(9): 1078-1092.

Barra, C., R. Lagravinese, and R. Zotti, 2015. "Explaining (in)efficiency in higher education: A comparison of parametric and non-parametric analyses to rank universities." MPRA Paper No. 67119. https://mpra.ub.uni-muenchen.de/67119/.

Charnes, A., W. Cooper, and E. Rhodes. 1978. "Measuring the efficiency of decision making units." European Journal of Operational Research 2: 429-444.

Coelli, T. J., D. S. Prasada Rao, C. J. O’Donnell, and G. E. Battese. 2005. An introduction to efficiency and productivity analysis. Springer Science \& Business Media.

Coelli, T. 1996. Assessing the performance of Australian universities using data envelopment analysis. NSW: Centre for Science and Productivity Analysis, University of New England. 
Council on Higher Education. 2016. South African higher education reviewed: Two decades of democracy. Pretoria: Council on Higher Education

Cunha, M. and V. Rocha. 2012. "On the efficiency of public higher education institutions in Portugal: An exploratory study." University of Porto, FEP Working Paper No. 468.

Department of Higher Education and Training. 2015. "Reflections on higher education transformation." Higher Education Summit: 1-24. http://www.dhet.gov.za/summit/Docs/2015 Docs/Annex\%203_DHET_Progress\%20with\%20transformation\%20_What\%20do\%20the \%20d ata\%20say.pdf.

DHET see Department of Higher Education and Training.

Duan, S. X. and H. Deng. 2016. Data envelopment analysis of the efficiency of Australian universities: An empirical study. Proceedings of the 20th Pacific Asia Conference on Information Systems, Chiayi, Taiwan, 27 June - 1 July 2016, 1-14.

Emrouznejad, A. and E. Cabanda, 2015. Introduction to Data Envelopment Analysis and its applications. In Handbook of research on strategic performance management and measurement using data envelopment analysis, ed. I. H. Osman, A. L. Anouze and A. Emrouznejad, 235-255. USA: IGI Global.

Emrouznejad, A., B. Parker, and G. Tavares 2008. A bibliography of data envelopment analysis. SocioEconomics Planning Science 42(3): 151-157.

Erkoç, T. E. 2016. "Measuring efficiencies of Turkish public universities with non-parametric efficiency estimation method." http://www.efdergi.hacettepe.edu.tr/upload/files/3429-nonparametric efficienci-estimation.pdf.

Farrell, M. 1957. "The measurement of productive efficiency". Journal of the Royal Statistical Society 120(3): 253-290.

Gromov, A. D. 2017. "The efficiency of Russian higher education institutions and its determinants." HSE Working paper WP BRP 40/EDU/2017. National Research University Higher School of Economics. SSRN: https://ssrn.com/abstract=2905028.

HESA see Higher Education South Africa.

Higher Education South Africa. 2008. Tuition fees: Higher education institutions in South Africa. Higher Education South Africa. https://www.justice.gov.za/commissions/FeesHET/docs/2008HESA-Report-TuitionFeesInSA.pdf.

Johnes, G. and J. Johnes. 1993. "Measuring the research performance of UK economics departments: An application of data envelopment analysis." Oxford Economic Papers 45: 332-347.

Johnes, J. 2008. "Efficiency and productivity change in the English higher education sector from 1996/97 to 2002/03." The Manchester School 76(6): 653-674.

Johnes, G. and K. Tone. 2017. "The efficiency of higher education institutions in England revisited: comparing alternative measures." Tertiary Education and Management 23(3): 191-205.

Johnstone, D. B. 2006. "Higher Education Finance and Accessibility: Tuition Fees and Student Loans in Sub-Saharan Africa." In Financing Higher Education, 201-226. Brill Sense.

Kotecha, P., M. Wilson-Strydom, and S. M. Fongwa. (Eds.). 2012. A profile of higher education in Southern Africa. Vol. 2: National perspectives. Johannesburg: SARUA.

Langa, P., G. Wangenge-Ouma, J. Jungblut, and N. Cloete, 2016. South Africa and the illusion of free higher education. University World News, 402. http://www.universityworldnews.com/ article.php?story $=20160223145336908$.

Levin, J. and P. Milgrom. 2004. "Producer Theory." https://web.stanford.edu/ jdlevin/Econ \%20202/Producer\%20Theory.pdf.

Madden, G., S. Savage, and S. Kemp. 1997. "Measuring public sector efficiency: A study of the Economics Department at Australian universities." Education Economics 5(2): 153-168.

Marire, J. 2017. "Are South African public universities economically efficient? Reflection amidst higher education crisis." South African Journal of Higher Education 31(3): 116-137. 
DOI: http://dx.doi.org/10.20853/31-3-1037.

Marwa, N. and M. Aziakpono. 2016. "Technical and scale efficiency of Tanzania saving and credit cooperatives." Journal of Developing Areas 50(1): 29-46.

Mattsson, P., J. Månsson, C. Andersson, and F. Bonander. 2018. "A bootstrapped Malmquist index applied to Swedish district courts." European Journal of Law and Economics 46(1): 109-139.

Meeusen, W. and J. van den Broeck. 1977. "Efficiency estimation from Cobb-Douglas production functions with composed error." International Economic Review 18(2): 435-444.

Myeki, L. W. and O. Temoso. 2019. "Efficiency assessment of public universities in South Africa, 2009-2013: Panel data evidence." South African Journal of Higher Education 33(5): 264-280.

Selim, S. and S. Bursalığlu. 2015. "Efficiency of higher education in Turkey: A bootstrapped two-stage DEA approach." International Journal of Statistics and Applications 5(2): 56-67.

Simar, L. and P. W. Wilson. 1998. "Sensitivity analysis of efficiency scores: How to bootstrap in nonparametric frontier models." Management Science 44(1): 49-61.

Srairi, S. 2014. "The efficiency of Tunisian universities: an application of a two-stage DEA approach." Journal of Knowledge Globalization 7(2): 31-57.

Statistics South Africa. 2012. Census 2011. https://www.statssa.gov.za/publications/P03014/ P030142011.pdf. (Accessed 26 January 2018).

Statistics South Africa. 2018. "Financial Statistics of Higher Education Institutions." http://www.statssa.gov.za/publications/P91031/P910312018.pdf.

Taylor, B. and G. Harris. 2004. "Relative efficiency among South African universities: A data envelopment analysis." Higher Education 47(1): 73-89.

Wangenge-Ouma, G. 2012. "Tuition fees and the challenge of making higher education a popular commodity in South Africa." Higher Education 64: 831-844.

Wangenge-Ouma, G. and N. Cloete. 2008. "Financing higher education in South Africa: Public funding, non-government revenue and tuition fees." South African Journal of Higher Education 22(4): 906-919.

Wolszczak-Derlacz, J. 2014. "An evaluation and explanation of (in)efficiency in higher education institutions in Europe and the U.S. with the application of two-stage semi-parametric DEA." IRLE Working paper No. 114-14. University of California. http://irle.berkeley.edu/workingpapers/11414.pdf.

Yuangyai, N. 2017. "The effects of public funding on efficiency of Thai public higher education institutions: A two-stage double-bootstrap Data Envelopment Analysis." Development Economic Review 11(2): 28-68. 


\section{APPENDIX}

Table 6: South African universities by category and province

\begin{tabular}{|c|c|c|c|c|}
\hline $\mathrm{DMU}_{\mathrm{s}}$ & University Name & University & Category & Province \\
\hline $\mathrm{DMU}_{1}$ & Cape Peninsula University of Technology & CPUT & University of Technology & Western Cape \\
\hline $\mathrm{DMU}_{2}$ & University of Cape Town & UCT & Traditional University & Western Cape \\
\hline $\mathrm{DMU}_{3}$ & Central University of Technology & CUT & University of Technology & Free State \\
\hline $\mathrm{DMU}_{4}$ & Durban University of Technology & DUT & University of Technology & KwaZulu-Natal \\
\hline $\mathrm{DMU}_{5}$ & University of Fort Hare & $\mathrm{FH}$ & Traditional University & Eastern Cape \\
\hline $\mathrm{DMU}_{6}$ & University of Free State & FS & Traditional University & Free State \\
\hline $\mathrm{DMU}_{7}$ & University of Johannesburg & UJ & Comprehensive University & Gauteng \\
\hline $\mathrm{DMU}_{8}$ & KwaZulu-Natal University & $\mathrm{KZN}$ & Traditional University & KwaZulu-Natal \\
\hline DMU9 & University of Limpopo & UL & Traditional University & Limpopo \\
\hline $\mathrm{DMU}_{10}$ & Nelson Mandela University & NMU & Comprehensive University & Eastern Cape \\
\hline $\mathrm{DMU}_{11}$ & North West University & NWU & Traditional University & North West \\
\hline $\mathrm{DMU}_{12}$ & University of Pretoria & UP & Traditional University & Gauteng \\
\hline $\mathrm{DMU}_{13}$ & Rhodes University & $\mathrm{RU}$ & Traditional University & Eastern Cape \\
\hline $\mathrm{DMU}_{14}$ & University of South Africa & UNISA & Comprehensive University & Gauteng \\
\hline $\mathrm{DMU}_{15}$ & University of Stellenbosch & SU & Traditional University & Western Cape \\
\hline $\mathrm{DMU}_{16}$ & Tshwane University of Technology Africa & TUT & University of Technology & Gauteng \\
\hline $\mathrm{DMU}_{17}$ & University of Venda & UNIVEN & Comprehensive University & Limpopo \\
\hline $\mathrm{DMU}_{18}$ & Vaal University of Technology & VUT & University of Technology & Gauteng \\
\hline $\mathrm{DMU}_{19}$ & Walter Sisulu University & WSU & Comprehensive University & Eastern Cape \\
\hline $\mathrm{DMU}_{20}$ & University of Western & UWC & Traditional University & Western Cape \\
\hline $\mathrm{DMU}_{21}$ & University of Witwatersrand & WITS & Traditional University & Gauteng \\
\hline $\mathrm{DMU}_{22}$ & University of Zululand & $\mathrm{UZ}$ & Comprehensive University & KwaZulu-Natal \\
\hline $\mathrm{DMU}_{23}$ & Mangosuthu University of Technology & MUT & University of Technology & KwaZulu-Natal \\
\hline
\end{tabular}


Table 7: Statistics summary for TE, PTE and SE scores for public universities in South Africa

\begin{tabular}{lccccc}
\hline Variable & Observations & Mean & Std. Dev. & Min & Max \\
\hline \hline CRS_TE & 184 & 0.9346 & 0.09664 & 0.5201 & 1.0000 \\
VRS_TE & 184 & 0.9603 & 0.08294 & 0.5300 & 1.0000 \\
SCALE & 184 & 0.9731 & 0.05121 & 0.6883 & 1.0000 \\
\hline
\end{tabular}

Table 8: Technical Efficiency scores for 23 South African public universities for the period 2009-2016

\begin{tabular}{|c|c|c|c|c|c|c|c|c|c|}
\hline University & DMU & 2009 & 2010 & 2011 & 2012 & 2013 & 2014 & 2015 & 2016 \\
\hline CPUT & 1 & 1.0000 & 1.0000 & 1.0000 & 1.0000 & 0.9814 & 0.9981 & 1.0000 & 0.9895 \\
\hline UCT & 2 & 1.0000 & 1.0000 & 1.0000 & 1.0000 & 1.0000 & 0.9883 & 0.9984 & 0.8692 \\
\hline CUT & 3 & 1.0000 & 1.0000 & 1.0000 & 1.0000 & 0.9404 & 0.9126 & 0.9555 & 0.9630 \\
\hline DUT & 4 & 1.0000 & 1.0000 & 1.0000 & 0.9912 & 1.0000 & 1.0000 & 1.0000 & 1.0000 \\
\hline $\mathrm{FH}$ & 5 & 0.8203 & 0.8739 & 0.9855 & 0.9449 & 0.9580 & 0.9208 & 0.8512 & 1.0000 \\
\hline FS & 6 & 0.9806 & 0.8651 & 0.9987 & 0.9817 & 1.0000 & 0.9678 & 0.9784 & 0.8626 \\
\hline UJ & 7 & 1.0000 & 1.0000 & 1.0000 & 0.8799 & 1.0000 & 1.0000 & 0.9644 & 0.9480 \\
\hline$K Z N$ & 8 & 0.7730 & 0.8511 & 0.9164 & 0.9517 & 0.9950 & 0.9749 & 1.0000 & 1.0000 \\
\hline UL & 9 & 0.7675 & 0.7205 & 0.6720 & 0.6975 & 0.7391 & 0.8274 & 1.0000 & 1.0000 \\
\hline NMU & 10 & 0.8899 & 0.9011 & 0.8850 & 0.9728 & 1.0000 & 0.9890 & 0.9171 & 0.9078 \\
\hline NWU & 11 & 1.0000 & 1.0000 & 1.0000 & 1.0000 & 1.0000 & 1.0000 & 1.0000 & 1.0000 \\
\hline UP & 12 & 1.0000 & 1.0000 & 1.0000 & 1.0000 & 1.0000 & 1.0000 & 1.0000 & 1.0000 \\
\hline $\mathrm{RU}$ & 13 & 1.0000 & 1.0000 & 1.0000 & 1.0000 & 1.0000 & 1.0000 & 1.0000 & 1.0000 \\
\hline UNISA & 14 & 1.0000 & 1.0000 & 1.0000 & 0.9278 & 1.0000 & 1.0000 & 1.0000 & 1.0000 \\
\hline SU & 15 & 1.0000 & 1.0000 & 1.0000 & 1.0000 & 1.0000 & 1.0000 & 1.0000 & 1.0000 \\
\hline TUT & 16 & 1.0000 & 1.0000 & 1.0000 & 0.8945 & 0.9927 & 0.9678 & 1.0000 & 1.0000 \\
\hline
\end{tabular}




\begin{tabular}{|c|c|c|c|c|c|c|c|c|c|}
\hline University & DMU & 2009 & 2010 & 2011 & 2012 & 2013 & 2014 & 2015 & 2016 \\
\hline UNIVEN & 17 & 0.8927 & 1.0000 & 0.8553 & 0.7214 & 0.6947 & 0.7028 & 0.6814 & 0.8308 \\
\hline VUT & 18 & 0.9875 & 0.9177 & 1.0000 & 0.8434 & 1.0000 & 0.9191 & 0.8929 & 0.8437 \\
\hline WSU & 19 & 0.5201 & 0.5421 & 0.7550 & 0.7403 & 0.7672 & 0.7797 & 0.8026 & 0.8028 \\
\hline UWC & 20 & 0.8710 & 0.8454 & 0.8897 & 0.8864 & 0.9486 & 0.9303 & 0.9189 & 0.9514 \\
\hline WITS & 21 & 0.9633 & 0.8628 & 0.9081 & 0.8720 & 1.0000 & 0.9760 & 0.9477 & 1.0000 \\
\hline UZ & 22 & 0.8208 & 0.8242 & 0.8511 & 1.0000 & 1.0000 & 1.0000 & 1.0000 & 1.0000 \\
\hline MUT & 23 & 0.6883 & 0.8026 & 0.8743 & 0.7318 & 0.9200 & 0.9856 & 0.9211 & 0.7837 \\
\hline \multicolumn{2}{|c|}{ Average } & 0.9120 & 0.9133 & 0.9387 & 0.9147 & 0.9538 & 0.9496 & 0.9491 & 0.9458 \\
\hline
\end{tabular}


Table 9: Pure Technical Efficiency scores for 23 South African public universities for the period 2009-2016

\begin{tabular}{|c|c|c|c|c|c|c|c|c|c|}
\hline University & DMU & 2009 & 2010 & 2011 & 2012 & 2013 & 2014 & 2015 & 2016 \\
\hline CPUT & 1 & 1.0000 & 1.0000 & 1.0000 & 1.0000 & 1.0000 & 1.0000 & 1.0000 & 1.0000 \\
\hline UCT & 2 & 1.0000 & 1.0000 & 1.0000 & 1.0000 & 1.0000 & 1.0000 & 1.0000 & 0.9474 \\
\hline CUT & 3 & 1.0000 & 1.0000 & 1.0000 & 1.0000 & 1.0000 & 1.0000 & 1.0000 & 1.0000 \\
\hline DUT & 4 & 1.0000 & 1.0000 & 1.0000 & 1.0000 & 1.0000 & 1.0000 & 1.0000 & 1.0000 \\
\hline $\mathrm{FH}$ & 5 & 0.9611 & 1.0000 & 1.0000 & 1.0000 & 1.0000 & 1.0000 & 1.0000 & 1.0000 \\
\hline FS & 6 & 0.9824 & 0.8682 & 1.0000 & 0.9833 & 1.0000 & 0.9702 & 0.9921 & 0.8735 \\
\hline UJ & 7 & 1.0000 & 1.0000 & 1.0000 & 1.0000 & 1.0000 & 1.0000 & 1.0000 & 1.0000 \\
\hline$K Z N$ & 8 & 0.8846 & 0.9427 & 0.9792 & 0.9999 & 1.0000 & 0.9758 & 1.0000 & 1.0000 \\
\hline UL & 9 & 0.7730 & 0.7475 & 0.6759 & 0.7216 & 0.7424 & 0.8274 & 1.0000 & 1.0000 \\
\hline NMU & 10 & 0.9056 & 0.9186 & 0.8871 & 0.9737 & 1.0000 & 0.9892 & 0.9194 & 0.9228 \\
\hline NWU & 11 & 1.0000 & 1.0000 & 1.0000 & 1.0000 & 1.0000 & 1.0000 & 1.0000 & 1.0000 \\
\hline UP & 12 & 1.0000 & 1.0000 & 1.0000 & 1.0000 & 1.0000 & 1.0000 & 1.0000 & 1.0000 \\
\hline RU & 13 & 1.0000 & 1.0000 & 1.0000 & 1.0000 & 1.0000 & 1.0000 & 1.0000 & 1.0000 \\
\hline UNISA & 14 & 1.0000 & 1.0000 & 1.0000 & 1.0000 & 1.0000 & 1.0000 & 1.0000 & 1.0000 \\
\hline SU & 15 & 1.0000 & 1.0000 & 1.0000 & 1.0000 & 1.0000 & 1.0000 & 1.0000 & 1.0000 \\
\hline TUT & 16 & 1.0000 & 1.0000 & 1.0000 & 1.0000 & 1.0000 & 1.0000 & 1.0000 & 1.0000 \\
\hline UNIVEN & 17 & 1.0000 & 1.0000 & 1.0000 & 0.7861 & 0.7385 & 0.8270 & 0.7632 & 0.8940 \\
\hline VUT & 18 & 1.0000 & 0.9647 & 1.0000 & 0.8669 & 1.0000 & 0.9211 & 0.9211 & 0.8776 \\
\hline WSU & 19 & 0.5300 & 0.5429 & 0.7586 & 0.7556 & 0.7712 & 0.7893 & 0.8116 & 0.8089 \\
\hline UWC & 20 & 0.9088 & 0.8947 & 0.9135 & 0.9132 & 0.9695 & 0.9551 & 0.9584 & 0.9534 \\
\hline WITS & 21 & 0.9678 & 0.8678 & 1.0000 & 0.8761 & 1.0000 & 0.9824 & 0.9478 & 1.0000 \\
\hline UZ & 22 & 0.9820 & 0.9627 & 0.9533 & 1.0000 & 1.0000 & 1.0000 & 1.0000 & 1.0000 \\
\hline MUT & 23 & 1.0000 & 1.0000 & 1.0000 & 1.0000 & 1.0000 & 1.0000 & 1.0000 & 1.0000 \\
\hline \multicolumn{2}{|c|}{ Average } & 0.9520 & 0.9439 & 0.9638 & 0.9511 & 0.9662 & 0.9668 & 0.9702 & 0.9686 \\
\hline
\end{tabular}


Table 10: Scale Efficiency scores for 23 South African public universities for the period 2009-2016

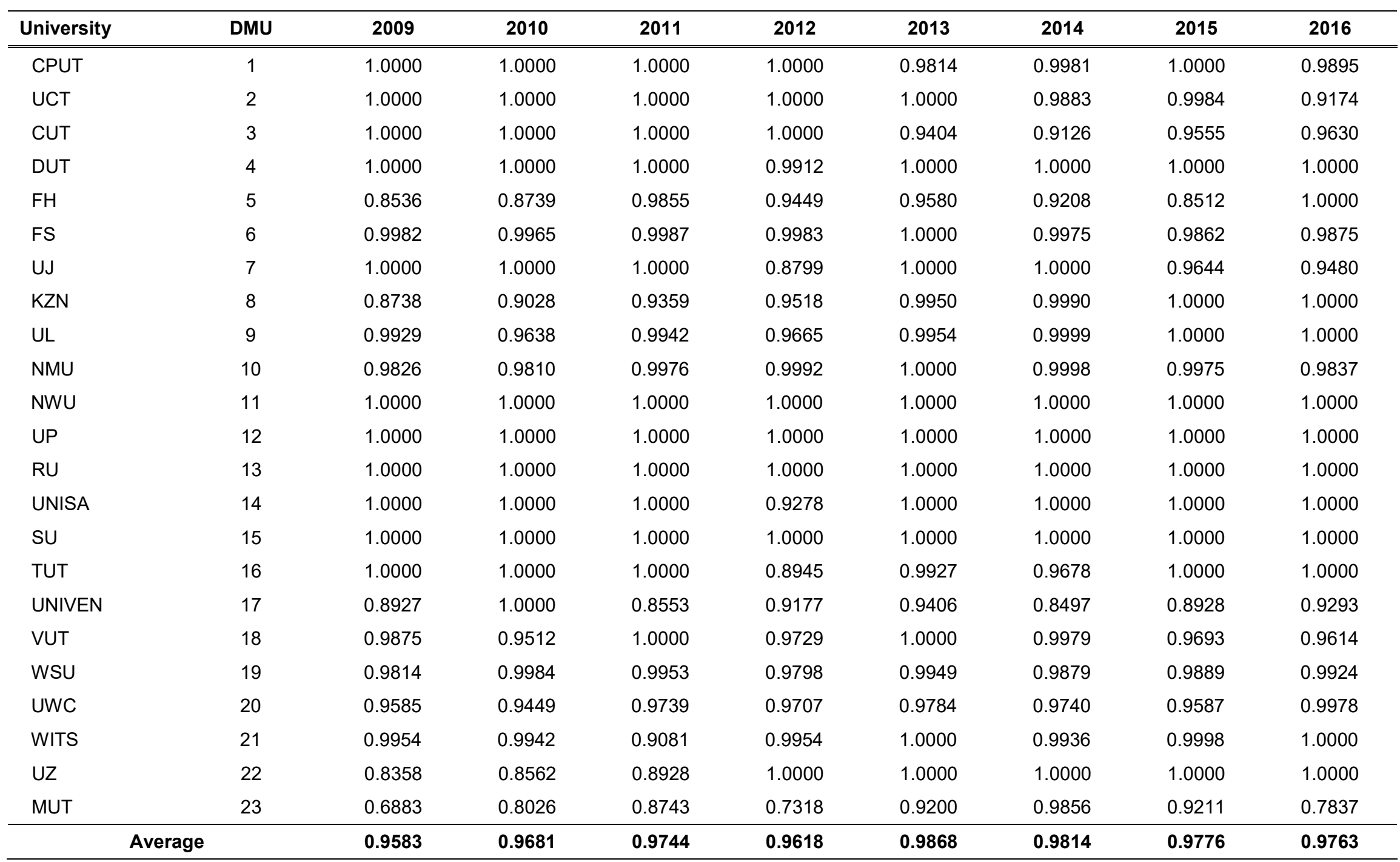


Table 11: Ranking of South African public universities by Technical Efficiency scores between 2009 and 2013

\begin{tabular}{|c|c|c|c|c|c|c|c|c|c|c|c|c|c|c|c|c|c|}
\hline \multirow{2}{*}{ University } & \multicolumn{9}{|c|}{ TE scores of public universities in South Africa } & \multicolumn{8}{|c|}{ Ranking of South African public universities by TE scores } \\
\hline & 2009 & 2010 & 2011 & 2012 & 2013 & 2014 & 2015 & 2016 & Average & 2009 & 2010 & 2011 & 2012 & 2013 & 2014 & 2015 & 2016 \\
\hline CPUT & 1.0000 & 1.0000 & 1.0000 & 1.0000 & 0.9814 & 0.9981 & 1.0000 & 0.9895 & 0.9961 & 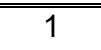 & 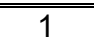 & $\overline{c 1}$ & $\overline{c 1}$ & 16 & 9 & $\overline{c 1}$ & 13 \\
\hline UCT & 1.0000 & 1.0000 & 1.0000 & 1.0000 & 1.0000 & 0.9883 & 0.9984 & 0.8692 & 0.9820 & 1 & 1 & 12 & 1 & 1 & 11 & 12 & 18 \\
\hline CUT & 1.0000 & 1.0000 & 1.0000 & 1.0000 & 0.9404 & 0.9126 & 0.9555 & 0.9630 & 0.9714 & 1 & 1 & 10 & 1 & 19 & 20 & 15 & 14 \\
\hline DUT & 1.0000 & 1.0000 & 1.0000 & 0.9912 & 1.0000 & 1.0000 & 1.0000 & 1.0000 & 0.9989 & 1 & 1 & 11 & 9 & 1 & 1 & 1 & 1 \\
\hline FH & 0.8203 & 0.8739 & 0.9855 & 0.9449 & 0.9580 & 0.9208 & 0.8512 & 1.0000 & 0.9193 & 19 & 15 & 14 & 13 & 17 & 18 & 21 & 1 \\
\hline FS & 0.9806 & 0.8651 & 0.9987 & 0.9817 & 1.0000 & 0.9678 & 0.9784 & 0.8626 & 0.9544 & 13 & 16 & 13 & 10 & 1 & 16 & 13 & 19 \\
\hline UJ & 1.0000 & 1.0000 & 1.0000 & 0.8799 & 1.0000 & 1.0000 & 0.9644 & 0.9480 & 0.9740 & 10 & 1 & 1 & 17 & 1 & 1 & 14 & 16 \\
\hline KZN & 0.7730 & 0.8511 & 0.9164 & 0.9517 & 0.9950 & 0.9749 & 1.0000 & 1.0000 & 0.9327 & 20 & 18 & 15 & 12 & 14 & 14 & 1 & 1 \\
\hline UL & 0.7675 & 0.7205 & 0.6720 & 0.6975 & 0.7391 & 0.8274 & 1.0000 & 1.0000 & 0.8030 & 21 & 22 & 23 & 23 & 22 & 21 & 1 & 1 \\
\hline NMU & 0.8899 & 0.9011 & 0.8850 & 0.9728 & 1.0000 & 0.9890 & 0.9171 & 0.9078 & 0.9328 & 16 & 14 & 18 & 11 & 1 & 10 & 19 & 17 \\
\hline NWU & 1.0000 & 1.0000 & 1.0000 & 1.0000 & 1.0000 & 1.0000 & 1.0000 & 1.0000 & 1.0000 & 11 & 1 & 1 & 1 & 12 & 1 & 1 & 1 \\
\hline UP & 1.0000 & 1.0000 & 1.0000 & 1.0000 & 1.0000 & 1.0000 & 1.0000 & 1.0000 & 1.0000 & 1 & 1 & 1 & 8 & 1 & 1 & 1 & 1 \\
\hline RU & 1.0000 & 1.0000 & 1.0000 & 1.0000 & 1.0000 & 1.0000 & 1.0000 & 1.0000 & 1.0000 & 1 & 1 & 1 & 1 & 1 & 1 & 1 & 1 \\
\hline UNISA & 1.0000 & 1.0000 & 1.0000 & 0.9278 & 1.0000 & 1.0000 & 1.0000 & 1.0000 & 0.9910 & 1 & 1 & 1 & 14 & 1 & 1 & 1 & 1 \\
\hline SU & 1.0000 & 1.0000 & 1.0000 & 1.0000 & 1.0000 & 1.0000 & 1.0000 & 1.0000 & 1.0000 & 1 & 1 & 1 & 1 & 1 & 1 & 1 & 1 \\
\hline TUT & 1.0000 & 1.0000 & 1.0000 & 0.8945 & 0.9927 & 0.9678 & 1.0000 & 1.0000 & 0.9819 & 1 & 1 & 9 & 15 & 15 & 15 & 11 & 1 \\
\hline UNIVEN & 0.8927 & 1.0000 & 0.8553 & 0.7214 & 0.6947 & 0.7028 & 0.6814 & 0.8308 & 0.7974 & 15 & 1 & 20 & 22 & 23 & 23 & 23 & 21 \\
\hline VUT & 0.9875 & 0.9177 & 1.0000 & 0.8434 & 1.0000 & 0.9191 & 0.8929 & 0.8437 & 0.9255 & 12 & 13 & 1 & 19 & 13 & 19 & 20 & 20 \\
\hline WSU & 0.5201 & 0.5421 & 0.7550 & 0.7403 & 0.7672 & 0.7797 & 0.8026 & 0.8028 & 0.7137 & 23 & 23 & 22 & 20 & 21 & 22 & 22 & 22 \\
\hline UWC & 0.8710 & 0.8454 & 0.8897 & 0.8864 & 0.9486 & 0.9303 & 0.9189 & 0.9514 & 0.9052 & 17 & 19 & 17 & 16 & 18 & 17 & 18 & 15 \\
\hline WITS & 0.9633 & 0.8628 & 0.9081 & 0.8720 & 1.0000 & 0.9760 & 0.9477 & 1.0000 & 0.9412 & 14 & 17 & 16 & 18 & 1 & 13 & 16 & 1 \\
\hline UZ & 0.8208 & 0.8242 & 0.8511 & 1.0000 & 1.0000 & 1.0000 & 1.0000 & 1.0000 & 0.9370 & 18 & 20 & 21 & 7 & 1 & 1 & 10 & 1 \\
\hline MUT & 0.6883 & 0.8026 & 0.8743 & 0.7318 & 0.9200 & 0.9856 & 0.9211 & 0.7837 & 0.8384 & 22 & 21 & 19 & 21 & 20 & 12 & 17 & 23 \\
\hline
\end{tabular}


Table 12: Summary of Peers for Output oriented VRS DEA in 2009

\begin{tabular}{|c|c|c|c|c|c|c|c|c|c|}
\hline \multirow{2}{*}{$\begin{array}{c}\text { University } \\
\text { CPUT }\end{array}$} & \multirow{2}{*}{$\begin{array}{c}\text { DMU } \\
1\end{array}$} & \multicolumn{4}{|c|}{ PEERs } & \multicolumn{4}{|c|}{ Output-oriented VRS DEA PEER weights } \\
\hline & & CPUT & 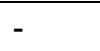 & - & 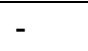 & 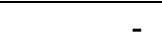 & 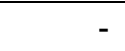 & - & - \\
\hline UCT & 2 & UCT & - & - & - & - & - & - & - \\
\hline CUT & 3 & CUT & - & - & - & - & - & - & - \\
\hline DUT & 4 & DUT & - & - & - & - & - & - & - \\
\hline $\mathbf{F H}$ & 5 & CPUT & RU & - & - & - & 0.2193 & 0.2036 & - \\
\hline FS & 6 & NWU & UP & RU & - & 0.1328 & 0.1869 & 0.6441 & - \\
\hline UJ & 7 & UJ & - & - & - & - & - & - & - \\
\hline KZN & 8 & CPUT & NWU & UP & $\mathrm{RU}$ & 0.2441 & 0.0197 & 0.0943 & 2.3149 \\
\hline UL & 9 & CPUT & $\mathrm{RU}$ & - & - & 0.3102 & 0.4144 & - & - \\
\hline NMU & 10 & CPUT & DUT & NWU & $\mathrm{RU}$ & 0.0921 & 0.1046 & 0.3240 & 0.1337 \\
\hline NWU & 11 & NWU & - & - & - & - & - & - & - \\
\hline UP & 12 & UP & - & - & - & - & - & - & - \\
\hline RU & 13 & $R U$ & - & - & - & - & - & - & - \\
\hline UNISA & 14 & UNISA & - & - & - & - & - & - & - \\
\hline SU & 15 & SU & - & - & - & - & - & - & - \\
\hline TUT & 16 & TUT & - & - & - & - & - & - & - \\
\hline UNIVEN & 17 & CUT & DUT & NWU & - & 0.0488 & 0.3222 & 0.0315 & - \\
\hline VUT & 18 & DUT & TUT & - & - & 0.4952 & 0.0343 & - & - \\
\hline WSU & 19 & CPUT & DUT & - & - & 0.3362 & 0.1056 & - & - \\
\hline UWC & 20 & CPUT & - & - & - & 0.1097 & - & - & - \\
\hline WITS & 21 & UP & SU & - & - & 0.1295 & 0.8152 & - & - \\
\hline UZ & 22 & CPUT & NWU & SU & TUT & 0.0348 & 0.0549 & 0.0323 & 0.1182 \\
\hline MUT & 23 & CPUT & TUT & - & - & $2.86 \mathrm{E}-08$ & 0.1149 & - & - \\
\hline
\end{tabular}


Table 13: Summary of Peers for Output oriented VRS DEA in 2016

\begin{tabular}{|c|c|c|c|c|c|c|c|c|c|c|c|}
\hline \multirow{2}{*}{$\begin{array}{l}\text { University } \\
\text { CPUT }\end{array}$} & \multirow{2}{*}{$\frac{\text { DMU }}{1}$} & \multicolumn{5}{|c|}{ PEERs } & \multicolumn{5}{|c|}{ Output-oriented VRS DEA PEER weights } \\
\hline & & DUT & - & - & - & - & 1.2014 & - & - & - & \\
\hline UCT & 2 & DUT & NWU & $\mathrm{RU}$ & - & - & 0.0175 & 0.0000 & 3.0620 & - & \\
\hline CUT & 3 & DUT & UNISA & UZ & - & - & 0.3545 & 0.0025 & 0.2447 & - & \\
\hline DUT & 4 & DUT & - & - & - & - & - & - & - & - & \\
\hline FH & 5 & $\mathrm{FH}$ & - & - & - & - & - & - & - & - & \\
\hline FS & 6 & $\mathrm{KZN}$ & NWU & su & - & - & 0.1515 & 0.2515 & 0.1181 & - & \\
\hline UJ & 7 & DUT & UP & $\mathrm{RU}$ & SU & UZ & 0.4041 & 0.0947 & 1.0433 & 0.0000 & 1.3647 \\
\hline KZN & 8 & $\mathrm{KZN}$ & - & - & - & - & - & - & - & - & - \\
\hline UL & 9 & UL & - & - & - & - & - & - & - & - & - \\
\hline NMU & 10 & DUT & $\mathrm{RU}$ & UZ & - & - & 0.1046 & 0.6726 & 0.9500 & - & - \\
\hline NWU & 11 & NWU & - & - & - & - & - & - & - & - & - \\
\hline UP & 12 & UP & - & - & - & - & - & - & - & - & - \\
\hline RU & 13 & $\mathrm{RU}$ & - & - & - & - & - & - & - & - & - \\
\hline UNISA & 14 & UNISA & - & - & - & - & - & - & - & - & - \\
\hline SU & 15 & SU & - & - & - & - & - & - & - & - & - \\
\hline TUT & 16 & TUT & - & - & - & - & - & - & - & - & - \\
\hline UNIVEN & 17 & DUT & UL & SU & WITS & - & 0.3299 & 0.0903 & 0.0203 & 0.0239 & - \\
\hline VUT & 18 & DUT & UNISA & - & - & - & 0.5508 & 0.0030 & - & - & - \\
\hline WSU & 19 & DUT & UNISA & - & - & - & 0.7426 & 0.0063 & - & - & - \\
\hline UWC & 20 & DUT & $\mathrm{FH}$ & UP & SU & & 0.0613 & 1.1878 & 0.0390 & 0.0163 & \\
\hline WITS & 21 & WITS & - & - & - & - & - & - & - & - & - \\
\hline UZ & 22 & UZ & - & - & - & - & - & - & - & - & - \\
\hline MUT & 23 & DUT & UNISA & UZ & - & - & 0.0407 & 0.0010 & 0.4312 & - & - \\
\hline
\end{tabular}

